\title{
Determination of Phosphorus Based on the Formation of a Reduced Keggin-Type 12-Molybdophosphate Complex in an Aqueous-Organic Solution
}

\author{
Tadaharu Ueda, ${ }^{\dagger}$ Masashi HoJo, and Kouhei SHIMIZu \\ Department of Material Science, Faculty of Science, Kochi University, Kochi 780-8520, Japan
}

\begin{abstract}
A very simple, easy and sensitive spectrophotometric manual determination method of phosphorus for the $\mathrm{PO}_{4}{ }^{3-}$ ion, based on the formation of the reduced 12-molybdophosphate complex, was developed. The effect of the kind of watermiscible organic solvent and the concentration of organic solvent, ascorbic acid and $\mathrm{HCl}$ on the formation of the complex was investigated. The optimum determination condition was confirmed based on these results. In an aqueous- $\mathrm{CH}_{3} \mathrm{CN}$ solution, a $\mathrm{P}_{-} \mathrm{PO}_{4}{ }^{3-}$ of $0.01-20 \mathrm{mg} \mathrm{l}^{-1}$ could thus be determined. It was noted that the determination range of this study was wider than that of the phosphoantimonylmolybdenum blue method $\left(0.032-1 \mathrm{mg} \mathrm{l}^{-1}\right)$. The effect of foreign ions on the absorbance was examined. The $\mathrm{P}_{-} \mathrm{PO}_{4}{ }^{3-}$ in river water and seawater sampled in Kochi was determined by this method. The results were also compared with those of the phosphoantimonylmolybdenum blue method and capillary electrophoresis with an indirect detection method using $\mathrm{K}_{2} \mathrm{CrO}_{4}$.
\end{abstract}

(Received July 2, 2001; Accepted Octorber 9, 2001)

\section{Introduction}

Extensive studies have been devoted to the determination of phosphorus as phosphate ion by the molybdenum blue method. There have been many reports on various modifications of this method in order to make the sensitivity and stability high. Various reductants, such as 1-amino-2-naphthol-4-sulfonic acid, stannous chloride(II), and ascorbic acid have been used to reduce the molybdophosphate complex. ${ }^{1-11}$ However, it is known to be difficult for methods using 1-amino-2-naphthol-4sulfonic acid and stannous chloride(II) to control both the $\mathrm{pH}$ and the temperature. ${ }^{12}$ It is also well known that solvent extraction with ethyl acetate, 1-butylalcohol, 2-methyl-1propylalcohol, and so on, makes the sensitivity high., ${ }^{5-21}$ Motomizu et al. reported that the formation of colored ionassociate between molybdophosphate and Malachite Green could be utilized to determine phosphorus in the ultra-trace range from 0.018 to $1.0 \mathrm{ng} \mathrm{cm}{ }^{-3} .22$ These highly sensitive methods contain a few careful procedures and require skill to determine $\mathrm{P}_{-} \mathrm{PO}_{4}{ }^{3-}$ with both high accuracy and precision. Molybdenum blue methods containing other metal ions, such as $\mathrm{Sb}$ (III), so-called phosphoantimonylmolybdenum blue method, has also usually been used as manual batch procedures., ${ }^{2,32.3}$ Blomqvist and Westin reported in detail the effect of $\mathrm{Cr}(\mathrm{VI})$, $\mathrm{Ge}(\mathrm{VI}), \mathrm{W}(\mathrm{VI})$, and $\mathrm{V}(\mathrm{V})$ ions that have easily reacted with heteropolyoxometalate on the absorbance measurement in the phosphoantimonylmolybdenum blue method. ${ }^{24}$ Various flowinjection analysis methods, that analyze phosphorus automatically, have also been developed..$^{2,3,25}$ It was also reported that organic phophorus and hydrolyzable phosphorus were converted into the orthophosphate ion for determining

$\doteqdot$ To whom correspondence should be addressed.

E-mail: chuji@cc.kochi-u.ac.jp
$\mathrm{P}-\mathrm{PO}_{4}{ }^{3-}, 3,4,25-27$

In a previous report, the formation conditions of molybdophosphate and -arsenate complexes in aqueous solution were confirmed. ${ }^{28}$ A few kinds of molybdophosphate complexes have been formed under high acidic conditions. The addition of water-miscible organic solvents, such as acetonitrile and acetone, made only 12-molybdophosphate stable. Maeda et al. examined the electrochemistry of 12-molybdophosphate in aqueous-organic solution..$^{29}$ The reduced form of 12molybdophosphate was found to be more stable in aqueousorganic solution than in aqueous solution. Based on these results, optimizing the formation conditions of the reduced 12molybdophosphate complex in aqueous-organic solution seems to enable one to determine a wider range of concentrations of $\mathrm{P}_{-} \mathrm{PO}_{4}{ }^{3-}$ than the phosphoantimonylmolybdenum blue method as a manual batch procedure.

\section{Experimental}

The absorption spectra were recorded on a Hitachi Model U2000 spectrophotometer using silica cells with path lengths of 0.1 and $1 \mathrm{~cm}$. Spectroscopic measurements under various conditions were made at $25 \pm 0.1^{\circ} \mathrm{C}$ without any baseline correction; those under the optimum determining conditions were made at room temperature. All of the reagents were of analytical grade, and were used as received.

\section{Results and Discussion}

Optimization of the formation conditions of the reduced 12molybdophosphate complex

Figure 1(a) shows the absorption spectrum for the $50 \mathrm{mM}(\mathrm{M}$

$\left.=\mathrm{mol} \mathrm{dm}{ }^{-3}\right) \mathrm{Mo}(\mathrm{VI})-1.0 \mathrm{M} \mathrm{HCl}-50 \%(\mathrm{v} / \mathrm{v}) \mathrm{CH}_{3} \mathrm{CN}-100 \mathrm{mM}$ 


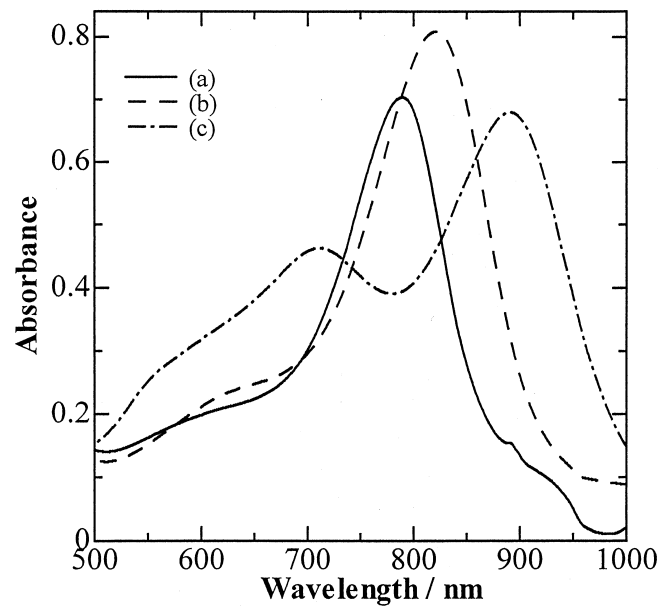

Fig. 1 Absorption spectra of reduced molybdophosphate complexes in aqueous-organic solution (a) and in aqueous solution (b), and the reduced phosphoantimonylmolybdenum complex in aqueous solution (c).

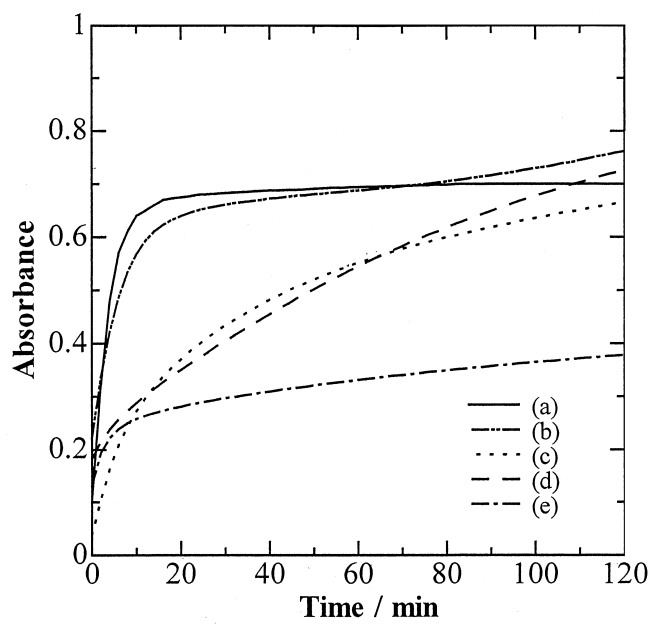

Fig. 2 Changes in the absorbance at $790 \mathrm{~nm}$ as a function of the reaction time at $25^{\circ} \mathrm{C}$ for a $50 \mathrm{mM} \mathrm{Mo}(\mathrm{VI})-1.0 \mathrm{M} \mathrm{HCl}-1 \mathrm{mg} \mathrm{l}^{-1} \mathrm{P}-$ $\mathrm{PO}_{4}{ }^{3-}-50 \%(\mathrm{v} / \mathrm{v})$ organic solvent $-100 \mathrm{mM}$ ascorbic acid system. The organic solvents were (a) acetonitrile, (b) acetone, (c) THF, (d) methanol, and (e) 1,4-dioxane.

ascorbic acid system containing $1 \mathrm{mg} \mathrm{l^{-1 }} \mathrm{P}_{-} \mathrm{PO}_{4}{ }^{3-}$. The absorption maximum appeared at $790 \mathrm{~nm}$. For a comparison, Figs. 1(b) and (c) show the absorption spectra for the $50 \mathrm{mM}$ $\mathrm{Mo}(\mathrm{VI})-1.0 \mathrm{M} \mathrm{HCl}-100 \mathrm{mM}$ ascorbic acid system and the $\mathrm{Mo}(\mathrm{VI})-\mathrm{Sb}$ (III)- $\mathrm{H}_{2} \mathrm{SO}_{4}$-ascorbic acid system (referred to the condition of Ref. 3), respectively, both containing $1 \mathrm{mg} \mathrm{l}^{-1}$ $\mathrm{P}_{-} \mathrm{PO}_{4}{ }^{3-}$. The absorption maxima appeared at 820 and $890 \mathrm{~nm}$, respectively. Figures 1 (a) and (b) indicate the formation of the reduced form of the 12-molybdophosphate anion, and Fig. 1(c) the formation of the reduced form of $\mathrm{PSb}_{2} \mathrm{Mo}_{10} \mathrm{O}_{40} \cdot{ }^{30}$ Harwood et al. demonstrated that the absorption spectrum for the $\mathrm{Mo}(\mathrm{VI})-\mathrm{Sb}(\mathrm{III})-\mathrm{H}_{2} \mathrm{SO}_{4}$-ascorbic acid system containing an excess of phosphate ion was identical to Fig. 1(b). ${ }^{31}$ This result indicated that the determination of phosphorus in a solution containing $>1 \mathrm{mg} \mathrm{l}^{-1} \mathrm{P}_{-} \mathrm{PO}_{4}{ }^{3-}$ was difficult, because the reduced forms of the $\mathrm{PSb}_{2} \mathrm{Mo}_{10} \mathrm{O}_{40}$ complex were converted into the reduced forms of the $\mathrm{PMo}_{12} \mathrm{O}_{40}$ complex. The absorbance at $790 \mathrm{~nm}$ was monitored, as discussed below, in solutions under

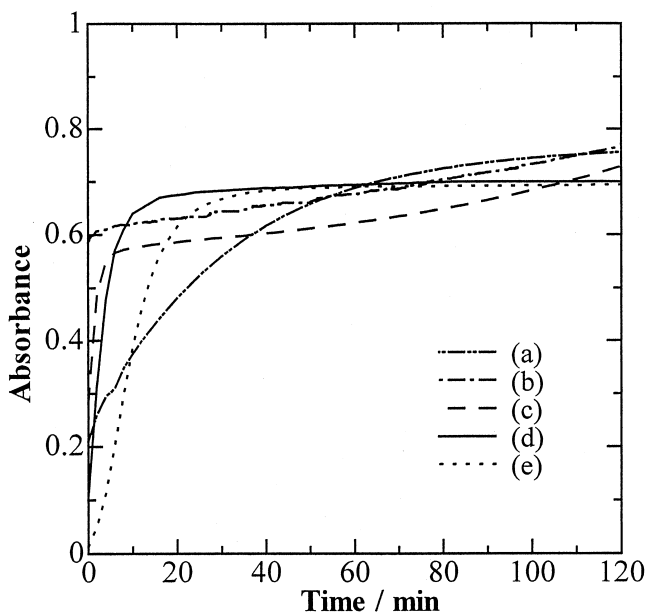

Fig. 3 Changes in the absorbance at $790 \mathrm{~nm}$ as a function of the reaction time at $25^{\circ} \mathrm{C}$ for a $50 \mathrm{mM} \mathrm{Mo}(\mathrm{VI})-1.0 \mathrm{M} \mathrm{HCl}-1 \mathrm{mg} \mathrm{l}^{-1} \mathrm{P}$ $\mathrm{PO}_{4}{ }^{3-}-100 \mathrm{mM}$ ascorbic acid system containig various amounts of acetonitrile. $\left[\mathrm{CH}_{3} \mathrm{CN}\right] / \%(\mathrm{v} / \mathrm{v})=$ (a) 0; (b) 30; (c) 40; (d) 50; (e) 60 .

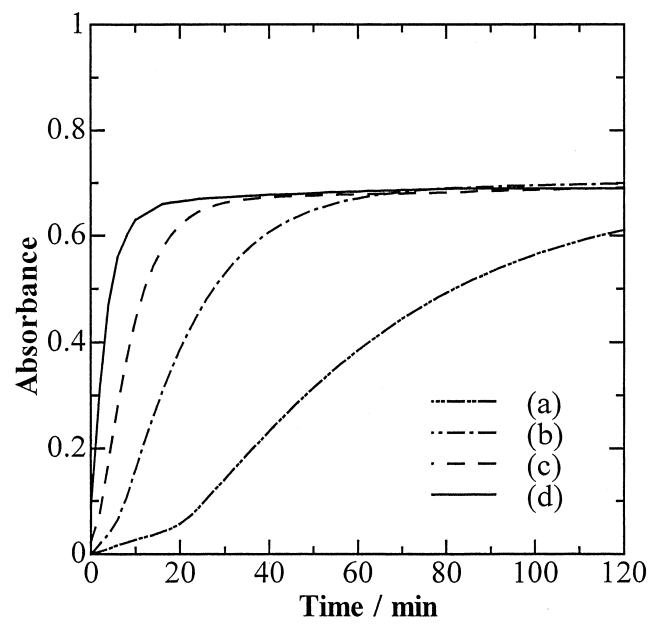

Fig. 4 Changes in the absorbance at $790 \mathrm{~nm}$ as a function of the reaction time at $25^{\circ} \mathrm{C}$ for a $50 \mathrm{mM} \mathrm{Mo}(\mathrm{VI})-1 \mathrm{mg} \mathrm{l}^{-1} \mathrm{P}_{-} \mathrm{PO}_{4}{ }^{3-}-50 \%$ (v/v) $\mathrm{CH}_{3} \mathrm{CN}$ system containing various concentration of ascorbic acid. [Ascorbic acid] $/ \mathrm{mM}=$ (a) 10; (b) 25; (c) 50; (d) 100.

various conditions to optimize the formation condition of reduced 12-molybdophosphate anion. In order to choose the best organic solvent in which reduced 12-molybdophosphate anions would form stably, the absorbance was measured as a function of the reaction time for $50 \mathrm{mM} \mathrm{Mo}(\mathrm{VI})-1.0 \mathrm{M} \mathrm{HCl}-1$ $\mathrm{mg} \mathrm{l}^{-1} \mathrm{P}_{-} \mathrm{PO}_{4}{ }^{3-}-100 \mathrm{mM}$ ascorbic acid containing various kinds of $50 \%(\mathrm{v} / \mathrm{v})$ organic solvents, such as acetonitrile, acetone, tetrahydrofuran, methanol, and 1,4-dioxane (Fig. 2). For a comparison, in aqueous solution, the measurement was also made as shown in Fig. 3(a). The absorbance kept increasing for at least $2 \mathrm{~h}$, except for that in $50 \%(\mathrm{v} / \mathrm{v})$ acetonitrile.

Figure 3 shows the change in the absorbance at $790 \mathrm{~nm}$ as a function of the reaction time for a $50 \mathrm{mM} \mathrm{Mo}(\mathrm{VI})-1.0 \mathrm{M} \mathrm{HCl}-1$ $\mathrm{mg} \mathrm{l}^{-1} \mathrm{P}_{-} \mathrm{PO}_{4}{ }^{3-}-100 \mathrm{mM}$ ascorbic acid system containing various amounts of $\mathrm{CH}_{3} \mathrm{CN}$. The absorbance was stable at $C_{\mathrm{CH}_{3} \mathrm{CN}}>50 \%$ $(\mathrm{v} / \mathrm{v})$. However, if $\mathrm{C}_{\mathrm{CH}_{3} \mathrm{CN}}>50 \%(\mathrm{v} / \mathrm{v})$ was added, the amount of the test solution became very small. Therefore, the amount of $\mathrm{CH}_{3} \mathrm{CN}$ in the mixed solution must be $50 \%$ (v/v).

In order to choose the best reductant, various reductants, such 


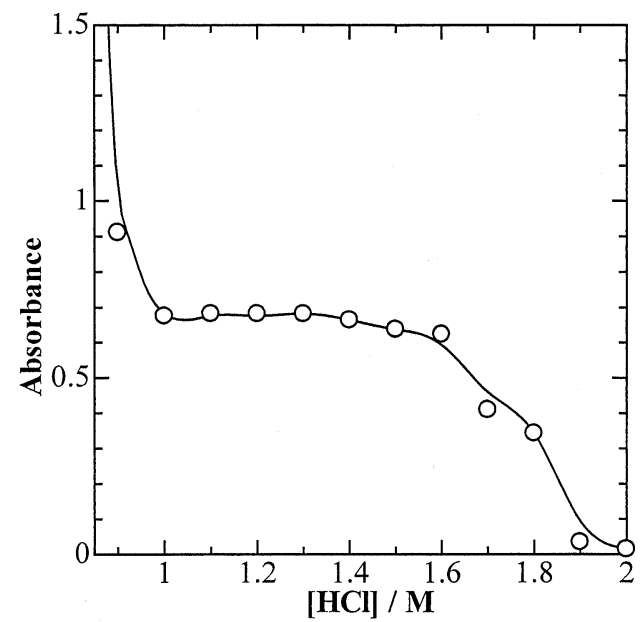

Fig. 5 Absorbance at $790 \mathrm{~nm}$ as a function of the $\mathrm{HCl}$

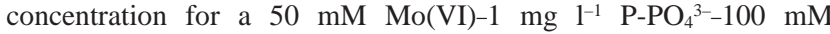
ascorbic acid-50\% (v/v) $\mathrm{CH}_{3} \mathrm{CN}$ system. The absorbance was measured after standing at room temperature for $1 \mathrm{~h}$. Path length, 1 $\mathrm{cm}$.

as stannnous chloride(II), hydrazine and ascorbic acid, were examined; but it was difficult to control the temperature and concentration of the acid and reductants, except for ascorbic acid. Figure 4 shows the change in the absorbance at $790 \mathrm{~nm}$ as a function of the reaction time for a $50 \mathrm{mM} \mathrm{Mo}(\mathrm{VI})-1.0 \mathrm{M}$ $\mathrm{HCl}-1 \mathrm{mg} \mathrm{l^{-1 }} \mathrm{P}_{-} \mathrm{PO}_{4}{ }^{3-}-50 \%$ (v/v) $\mathrm{CH}_{3} \mathrm{CN}$ system containing various concentrations of ascorbic acid. When more than 25 $\mathrm{mM}$ of ascorbic acid was added, the absorbance ultimately became the same value. With increasing concentration of ascorbic acid, the absorbance quickly became unchangeable. At [ascorbic acid] $=100 \mathrm{mM}$, it required $\mathrm{ca}$. $30 \mathrm{~min}$ to achieve a constant value of the absorbance. When the solution was heated, the color of the solution turned blue and the absorbance quickly became constant in spite of the low concentration of ascorbic acid. However, heating the solution was excluded from the set of determination procedures for simplicity.

In order to obtain the limiting conditions of the reduced 12-molybdophosphate complex, the absorbance was measured for a series of $50 \mathrm{mM} \mathrm{Mo}(\mathrm{VI})-1 \mathrm{mg} \mathrm{l^{-1 }} \mathrm{P}_{-} \mathrm{PO}_{4}{ }^{3-}-100 \mathrm{mM}$ ascorbic acid-50\% (v/v) $\mathrm{CH}_{3} \mathrm{CN}$ systems containing various concentrations of $\mathrm{HCl}(0.7-2.0 \mathrm{M})$. Even in the absence of phosphate ions, the solution gave a blue color due to the reduced isopolymolybdates at $[\mathrm{HCl}]<1.0 \mathrm{M}$. Therefore, the increment of the absorbance at $[\mathrm{HCl}]<1.0 \mathrm{M}$ (Fig. 5), was attributed to the formation of reduced isopolymolybdates and reduced 12-molybdophosphate. It was found that the reduced 12-molybdophosphate anion was obtained at up to $1.9 \mathrm{M}$ of $\mathrm{HCl}$ concentration. At $[\mathrm{HCl}]=1.0-1.3 \mathrm{M}$, the absorbance was constant. These results indicated that the optimum condition for the determination was $50 \mathrm{mM} \mathrm{Mo(VI)-1.0} \mathrm{-} \mathrm{1.3} \mathrm{M} \mathrm{HCl-100}$ $\mathrm{mM}$ ascorbic acid-50\% (v/v) $\mathrm{CH}_{3} \mathrm{CN}$. Finally, the acid concentration was chosen to be $1.2 \mathrm{M}$, while taking into account of interference from the $\mathrm{Si}(\mathrm{IV})$ ion (see below) and the preparation of the stock solution.

\section{Recommended procedure}

A stock solution of $1 \mathrm{M}$ ascorbic acid was prepared for every measurement. A $1.0984 \mathrm{~g}$ quantity of $\mathrm{KH}_{2} \mathrm{PO}_{4}{ }^{3-}$, which had been dried for $2 \mathrm{~h}$ in an oven at $110^{\circ} \mathrm{C}$, was dissolved in $250 \mathrm{ml}$ of distilled water $\left(1000 \mathrm{mg} \mathrm{l}^{-1} \mathrm{P}_{-} \mathrm{PO}_{4}{ }^{3-}\right)$. An aqueous solution containing $12.0975 \mathrm{~g}$ of $\mathrm{Na}_{2} \mathrm{MoO}_{4} \cdot 2 \mathrm{H}_{2} \mathrm{O}$ and $104 \mathrm{ml}$ of conc.

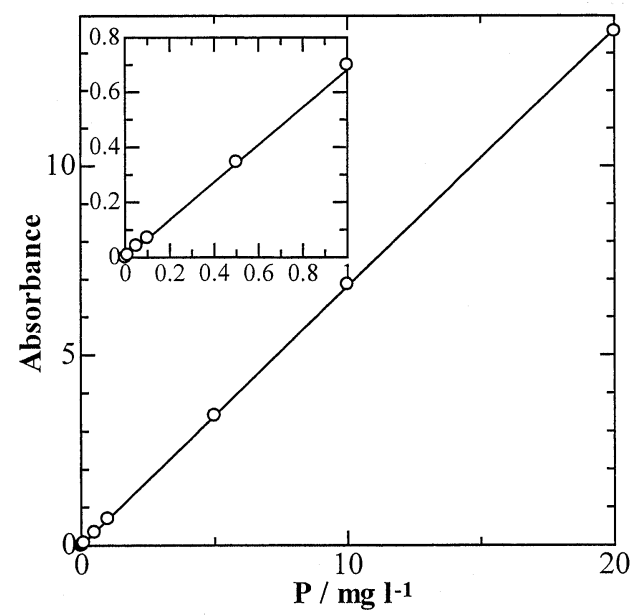

Fig. 6 Calibration curve of $\mathrm{P}_{-} \mathrm{PO}_{4}{ }^{3-}$ for a $50 \mathrm{mM} \mathrm{Mo}(\mathrm{VI})-1.2 \mathrm{M}$ $\mathrm{HCl}-100 \mathrm{mM}$ ascorbic acid-50\% (v/v) $\mathrm{CH}_{3} \mathrm{CN}$ system. The absorbance at $790 \mathrm{~nm}$ was measured after standing at room temperature for $1 \mathrm{~h}$ and is shown as the value for a $1 \mathrm{~cm}$ path length.

Table 1 Effects of foreign ions on the determination of $\mathrm{P}$ $\mathrm{PO}_{4}{ }^{3-}$

\begin{tabular}{|c|c|c|c|}
\hline & $\begin{array}{c}\text { Concentration/ } \\
\mathrm{mg} \mathrm{l}^{-1}\end{array}$ & Absorbance & $\begin{array}{c}\text { Relative error, } \\
\%\end{array}$ \\
\hline None & & 0.687 & \\
\hline $\mathrm{Na}^{+}$ & 1000 & 0.689 & +0.3 \\
\hline $\mathrm{K}^{+}$ & 1000 & 0.689 & +0.3 \\
\hline $\mathrm{Mg}^{2+}$ & 1000 & 0.702 & +2.2 \\
\hline $\mathrm{Ca}^{2+}$ & 1000 & 0.700 & +1.9 \\
\hline \multirow[t]{2}{*}{$\mathrm{V}(\mathrm{V})$} & 10 & 0.694 & +1.0 \\
\hline & 1 & 0.687 & 0 \\
\hline $\mathrm{Fe}(\mathrm{II})$ & 10 & 0.706 & +2.6 \\
\hline \multirow[t]{2}{*}{$\mathrm{N}-\mathrm{NO}_{3}{ }^{-}$} & 10 & 0.685 & -0.3 \\
\hline & 1 & 0.688 & +0.1 \\
\hline \multirow[t]{2}{*}{$\mathrm{N}-\mathrm{NO}_{2}^{-}$} & 10 & 0.662 & -3.6 \\
\hline & 1 & 0.686 & -0.1 \\
\hline \multirow[t]{2}{*}{$\mathrm{S}-\mathrm{SO}_{4}{ }^{2-}$} & 10 & 0.686 & -0.1 \\
\hline & 1 & 0.683 & -0.6 \\
\hline \multirow[t]{2}{*}{$\mathrm{S}-\mathrm{SO}_{3}{ }^{2-}$} & 10 & 0.689 & +0.3 \\
\hline & 1 & 0.689 & +0.3 \\
\hline \multirow[t]{2}{*}{$\mathrm{Si}(\mathrm{IV})$} & 10 & 0.692 & +0.7 \\
\hline & 1 & 0.690 & +0.4 \\
\hline $\mathrm{As}-\mathrm{AsO}_{4}{ }^{3-}$ & 1 & 1.028 & +49.6 \\
\hline $\mathrm{P}_{-} \mathrm{PHO}_{3}{ }^{2-}$ & 1 & 0.713 & +3.8 \\
\hline $\mathrm{P}-\mathrm{P}_{2} \mathrm{O}_{7}^{4-}$ & 1 & 1.079 & +57.1 \\
\hline
\end{tabular}

$\left[\mathrm{P}_{-} \mathrm{PO}_{4}{ }^{3-}\right]=1 \mathrm{mg} \mathrm{l^{-1 }}$. $50 \mathrm{mM} \mathrm{Mo}(\mathrm{VI})-1.2 \mathrm{M} \mathrm{HCl}-100 \mathrm{mM}$ ascorbic acid-50\% (v/v) $\mathrm{CH}_{3} \mathrm{CN}$. Measured after standing at room temperature for $1 \mathrm{~h}$. Path length, $1 \mathrm{~cm}$.

$\mathrm{HCl}$ was placed in a $250 \mathrm{ml}$ volumetric flask, which was diluted to the mark with distilled water. This solution was stable in a polyethylene bottle for at least 2 months. A $5 \mathrm{ml}$ aliquot of the $\mathrm{Mo}(\mathrm{VI})-\mathrm{HCl}$ solution and $10 \mathrm{ml}$ of $\mathrm{CH}_{3} \mathrm{CN}$ were placed in a 20 $\mathrm{ml}$ volumetric flask. To the mixture were added an appropriate volume of the sample solution and $2 \mathrm{ml}$ of the ascorbic acid stock solution; the solution was then diluted to the mark with distilled water and left standing for $1 \mathrm{~h}$ at room temperature. The absorbance at $790 \mathrm{~nm}$ was measured, while referring to the blank solution. The determination range of $\mathrm{P}_{-} \mathrm{PO}_{4}{ }^{3-}$ in an aqueous- $\mathrm{CH}_{3} \mathrm{CN}$ solution was from 0.01 to $20 \mathrm{mg} \mathrm{l}^{-1}$, as shown in Fig. 6. This is wider than that of the phosphoantimonylmolybdenum blue method, of which the 
Table 2 Phosphorus, $\mathrm{pH}$ and conductivity in river water and seawater samples

\begin{tabular}{|c|c|c|c|c|c|}
\hline Sampling point & $\mathrm{pH}$ & $\begin{array}{c}\text { Conductivity/ } \\
\mu \mathrm{S}\end{array}$ & $\begin{array}{c}\text { Method } \mathrm{A}^{\mathrm{a}} \text { } \\
\mathrm{mg} \mathrm{l}^{-1}\end{array}$ & $\begin{array}{c}\text { Method B }{ }^{\mathrm{b}} \\
\mathrm{mg} \mathrm{l}^{-1}\end{array}$ & $\begin{array}{c}\text { Method Ce/ } \\
\mathrm{mg} \mathrm{l}^{-1}\end{array}$ \\
\hline Kagami river & 7.9 & 79 & $<0.032$ & $\mathrm{ND}^{\mathrm{d}}$ & $<0.01$ \\
\hline Yoshino river & 7.2 & 161 & 0.14 & ND & 0.15 \\
\hline Enoguchi river & 7.1 & 6200 & 0.22 & 0.21 & 0.22 \\
\hline Kochi harbor & 7.2 & 8100 & 0.08 & ND & 0.08 \\
\hline
\end{tabular}

a. Phosphoantimonylmolybdenum blue method. b. Capillary electrophoresis using indirect method. c. This study. d. Not detected.

determination range has been reported to be $0.032-1 \mathrm{mg}^{-1} .{ }^{32}$ The concentration of $\mathrm{P}_{-} \mathrm{PO}_{4}{ }^{3-}$ was determined by the corresponding calibration curve.

\section{Interference from foreign ions}

The effects of foreign ions on the determination of phosphorus are listed in Table 1. Since the excess amounts of alkaline and alkaline earth metals in a sample solution have not affected the formation of reduced 12-molybdophosphate, this method could be applied to the determination of phosphorus in seawater. A large amount of ascorbic acid had little effect on oxidants, such as nitrate and nitrite ions. It is known that the formation conditions of reduced molybdosilicates are less acidic than those of reduced molybdophophates. ${ }^{33}$ Under the optimum analytical conditions, the silicate ion had only a small effect on the determination. When the determination condition of the 50 $\mathrm{mM}$ Mo(VI)-1.0 M HCl-100 mM ascorbic acid-50\% (v/v) $\mathrm{CH}_{3} \mathrm{CN}$ system was applied, the silicate ion caused significant interference. Unfortunately, the arsenate ion interfered, since the reduced 12-molybdoarsenate as well as the reduced 12molybdophosphate had formed in an aqueous- $\mathrm{CH}_{3} \mathrm{CN}$ solution. Previously, heteropolymolybdates containing $\mathrm{PHO}_{3}{ }^{2-}$ and $\mathrm{P}_{2} \mathrm{O}_{7}{ }^{4-}$ were prepared and characterized in aqueous-acetonitrile and -acetone solutions. ${ }^{34,35}$ Based on these formation reactions, the direct spectrophotometric determination method of $\mathrm{PHO}_{3}{ }^{2-}$ and $\mathrm{P}_{2} \mathrm{O}_{7}^{4-}$ ions in an aqueous-acetone solution was also developed. ${ }^{36}$ In fact, $\mathrm{PHO}_{3}{ }^{2-}$ and $\mathrm{P}_{2} \mathrm{O}_{7}{ }^{4-}$ ions also brought about positive errors in an aqueous- $\mathrm{CH}_{3} \mathrm{CN}$ solution. If we try to determine $\mathrm{P}_{-} \mathrm{PO}_{4}{ }^{3-}$ in sample solutions containing an excess of $\mathrm{AsO}_{4}{ }^{3-}, \mathrm{PHO}_{3}{ }^{2-}$, and $\mathrm{P}_{2} \mathrm{O}_{7}{ }^{4-}$ ions, they must be analyzed by other methods, such as atomic absorption spectroscopy, inductively coupled argon-plasma emission spectroscopy, and ion chromatography. However, since it has been well known that the concentrations of $\mathrm{AsO}_{4}{ }^{3-}, \mathrm{PHO}_{3}{ }^{2-}$, and $\mathrm{P}_{2} \mathrm{O}_{7}{ }^{4-}$ ions in river and seawater are much less than that of the $\mathrm{PO}_{4}{ }^{3-}$ ion, they should not interfere seriously with the determination..$^{23,37,38}$

Analysis of phosphorus in river and seawater, and comparison with the other methods

The present method was applied to the determination of phosphorus in water sampled from a few rivers in Kochi city and Kochi harbor. For a comparison, the same water samples were also analyzed by the phosphoantimonylmolybdenum blue method and by capillary electrophoresis with an indirect method $\left(\mathrm{K}_{2} \mathrm{CrO}_{4}\right.$ reagent). ${ }^{39}$ These results are listed in Table 2. The $\mathrm{pH}$ and conductivity of the sample waters were also measured. The results obtained by the method used in this study coincided well with those of other methods.

\section{References}

1. "Treatise on Analytical Chemistry", ed. I. M. Kolthoff and
P. J. Elving, 1961, Vol. 5, Interscience, New York, 317.

2. K. Robards, I. D. McKelvie, R. L. Benson, P. J. Worsfold, N. J. Blundell, and H. Casey, Anal. Chim. Acta, 1994, 287, 147.

3. "Standard Methods for the Examination of Water and Wastewater", ed. A. D. Eaton, L. S. Clesceri, and A. E. Greenberg, 1995, Chap. 4, American Public Health Association, Washington, D.C., 106.

4. "Annual Book of ASTM Standards, Section 11-Water and Environmental Technology", 1996, American Society for Testing and Materials, Philadelphia, 24.

5. N. S. Ging, Anal. Chem., 1956, 28, 1330.

6. R. E. Kitson and M. G. Mellon, Ind. Eng. Chem., Anal. Ed., 1944, 16, 446.

7. P. S. Chen, Jr., T. Y. Toribara, and H. Warner, Anal. Chem., 1956, 28, 1756.

8. M. Rockstein and P. W. Herron, Anal. Chem., 1951, 23, 1500.

9. G. R. Nakamura, Anal. Chem., 1952, 24, 1372.

10. A. P. Briggs, J. Biol. Chem., 1922, 53, 13.

11. M. Codell and J. J. Mikula, Anal. Chem., 1953, 25, 1444.

12. J. D. Burton and J. P. Riley, Mikrochim. Acta, 1956, 9, 1350.

13. J. Hure and T. Ortis, Bull. Chem. Soc. Chim. France, 1949, 834.

14. W. Fischer, P. Rudiger, and H. J. Abendroth, Anal. Chim. Acta, 1955, 13, 38.

15. C. Wadelin and M. G. Mellon, Analyst, 1952, 77, 708.

16. I. Berenblum and E. Chain, Biochem. J., 1938, 32, 287.

17. F. L. Schaffer, J. Fong, and P. L. Kirk, Anal. Chem., 1953, 25,343

18. C. H. Lueck and D. F. Boltz, Anal. Chem., 1956, 28, 1168.

19. M. Ishibashi and M. Tabushi, Bunseki Kagaku, 1959, 8, 588.

20. F. L. Schaffer, J. Fong, and P. L. Kirk, Anal. Chem., 1953, 25,343 .

21. J. B. Martin and D. M. Doty, Anal. Chem., 1949, 21, 965.

22. S. Motomizu, J. P. Susanto, M. Oshima, H. Mikasa, and Y. Hori, Anal. Sci., 1995, 11, 155.

23. J. Murphy and J. P. Riley, Anal. Chim. Acta, 1962, $27,31$.

24. S. Blomqvist and S. Westin, Anal. Chim. Acta, 1998, 358, 245.

25. K. Higuchi, H. Tamanouchi, and S. Motomizu, Anal. Sci., 1998, 14, 941.

26. J. Kolmerten and J. Epstein, Anal. Chem., 1958, 30, 1536.

27. B. L. Griswold, F. L. Humoller, and A. R. McIntyre, Anal. Chem., 1951, 23, 192.

28. S. Himeno, M. Hashimoto, and T. Ueda, Inorg. Chim. Acta, 1999, 284, 237.

29. K. Maeda, S. Himeno, T. Osakai, A. Saito, and T. Hori, $J$. Electroanal. Chem., 1994, 364, 149.

30. J. E. Going and S. J. Eisenreich, Anal. Chim. Acta, 1974, 70,95 . 
31. J. E. Harwood, R. A. van Steenderen, and A. L. Kuhn, Water Res., 1969, 3, 417.

32. "Gesui Shiken Houhou (in Japanese)", ed. Nihon Gesuidou Kyoukai, 1997, Tokyo, 192.

33. H. Levine, J. J. Rowe, and F. S. Grimaldi, Anal. Chem., 1955, 27, 258.

34. T. Ueda, K. Sano, S. Himeno, and T. Hori, Bull. Chem. Soc. Jpn., 1997, 70, 1093.
35. S. Himeno, T. Ueda, M. Shiomi, and T. Hori, Inorg. Chim. Acta, 1997, 262, 219.

36. S. Himeno, T. Ueda, H. Niiya, I. Iwai, and T. Hori, Anal. Sci., 1997, 13, 369.

37. T. Nasu and M. Kan, Analyst, 1988, 113, 1683.

38. P. Hoffmann, I. Schmidtke, and K. H. Lieser, Fresenius Z. Anal. Chem., 1989, 335, 402.

39. P. Kubáň and V. Kubáň, J. Chromatogr. A, 1999, 848, 545. 